University of Nebraska - Lincoln

DigitalCommons@University of Nebraska - Lincoln

4-1975

\title{
Fatal Pox Infection in a Rough-Legged Hawk
}

\author{
G. L. Pearson \\ U.S. Fish and Wildlife Service \\ D. A. Pass \\ University of Guelph \\ E. C. Beggs \\ University of Guelph
}

Follow this and additional works at: https://digitalcommons.unl.edu/usgsnpwrc

Part of the Other International and Area Studies Commons

Pearson, G. L.; Pass, D. A.; and Beggs, E. C., "Fatal Pox Infection in a Rough-Legged Hawk" (1975). USGS Northern Prairie Wildlife Research Center. 112.

https://digitalcommons.unl.edu/usgsnpwrc/112

This Article is brought to you for free and open access by the US Geological Survey at DigitalCommons@University of Nebraska - Lincoln. It has been accepted for inclusion in USGS Northern Prairie Wildlife Research Center by an authorized administrator of DigitalCommons@University of Nebraska - Lincoln. 


\title{
FATAL POX INFECTION IN A ROUGH-LEGGED HAWK
}

\author{
G. L. PEARSON, U.S. Fish and Wildlife Service, Northern Prairie Wildlife Research Center, \\ Jamestown, North Dakota 58401, U.S.A. \\ D. A. PASS and E. C. BEGGS, Department of Pathology, Ontario Veterinary College, \\ University of Guelph, Guelph, Ontario, Canada NIG 2W1.
}

\begin{abstract}
Natural pox infection occurred in a free-living rough-legged hawk (Buteo lagopus) in northeastern North Dakota. Gross, histological and electron microscopic findings were typical of pox infection, and characteristic lesions developed in red-tailed hawks (Buteo jamaicensis) but not in great horned owls (Bubo virginianus) following inoculation with case material. Death of the rough-legged hawk was attributed to starvation resulting from inability to capture prey and to blood loss from foot lesions.
\end{abstract}

\section{INTRODUCTION}

Pox infections in birds of prey have been known for some time, ${ }^{1,7}$ although reports of natural infections in specific raptor species, espectilly under wild conditions, are few. Cooper ${ }^{3}$ reported pox infections in two captive peregrine falcons (Falco peregrinus) which apparently developed extensive lesions and were destroyed. A captive saker falcon (Falco cherrug) was reported by Greenwood and Blakemore" to have recovered from pox infection, even though extensive foot lesions had developed and one talon had been lost. Halliwell ${ }^{5}$ described a non-fatal case of pox in a captive immature redtailed hawk, and Moffat ${ }^{8}$ reported a naturally occurring pox infection in a freeflying juvenile golden eagle (Aquila chrysaetos) but did not indicate the outcome.

Most reported cases of pox infections in free-flying wild birds have been mild and self-limiting; however, lesions resulting in impaired vision may result in severe mortality from starvation in some cases. ${ }^{6}$ This paper reports an additional hazard of pox infection in a bird of prey.

\section{Case History}

A female rough-legged hawk captured December 2, 1971, by a farmer in Ramsey County, North Dakota, was delivered to the manager of the Sullys Hill National Game Preserve, Fort Totten, North Dakota. The hawk had been observed in the vicinity of the farmstead for several days and at the time of capture was weak and unable to fly. A large, irregular mass involving the left foot made walking difficult. Although the hawk fed on muskrat carcasses provided at the preserve, movement and feeding activity caused bleeding of the foot, and the bird was found dead on December 5 .

\section{MATERIALS AND METHODS}

\section{Case Material}

The rough-legged hawk was frozen after death. Before thawing for necropsy, sections of cutaneous lesions were collected and maintained in a frozen state for virological studies while others were fixed in $10 \%$ formalin for histopathological examination. A sample of frozen 
skin nodule was prepared by the method outlined by Cheville, ${ }^{2}$ negatively stained with $2 \%$ phosphotungistic acid at $\mathrm{pH}$ 4.3 , and examined with a Philips 200 electron microscope at $60 \mathrm{KV}$. The formalin fixed tissues were processed routinely, embedded in paraffin, sectioned at $6 \mu \mathrm{m}$, and stained with hematoxylin and eosin for conventional light microscopy.

\section{Transmission Studies}

Two red-tailed hawks and two great horned owls were used for transmission studies. An area approximately $0.5 \mathrm{~cm}^{2}$ on the scaly area of the distal tarsometatarsus of the hawks and on the soft skin between the digits of the owls was scarified with the tip of an 18-gauge hypodermic needle. Approximately 0.2 $\mathrm{ml}$ of the virus inoculum prepared ${ }^{2}$ from a skin nodule of the rough-legged hawk was rubbed into the scarified areas.

At 49 days post-inoculation, a nodu'e which developed at the inoculation site on one red-tailed hawk was removed by excision biopsy. One half of the lesion was fixed in $10 \%$ formalin and the other half was fixed in 5\% glutaraldehyde for 4 hours. The formalin fixed material was processed and stained in the same manner as the case material described above. The tissue fixed in glutaraldehyde was washed in sucrose phosphate buffer, post-fixed in $1 \%$ phosphate buffered osmium tetroxide for 1 hour, dehydrated through a graded series of acetone solutions, and embedded in Epon 812*. Ultrathin sections were stained with lead citrate $^{\circ}$ and $2 \%$ aqueous uranyl acetate and then examined with a Philips 200 electron microscope at $60 \mathrm{KV}$.

\section{RESULTS}

\section{Case Maforial}

Gross pathological examination of the rough-legged hawk revealed an extensive ( $8 \times 8 \times 5 \mathrm{~cm}$ ), irregular, dark, encrusted mass involving the entire left foot and resulting in sloughing of the talons from the anterior digits (Figure 1). Three small $(0.5-1.0 \mathrm{~cm})$, raised, dark, encrusted lesions were present on the right foot. Similar lesions were also present on the lower left palpebra, on the cere, and at the commisures and on the right lingual surfaces of the beak, but were not sufficiently extensive to have interefered with vision or ingestion. The hawk, which was severely emaciated, weighed $708 \mathrm{~g}$. The blood appeared pale and watery, the gallbladder was distended, and the cloaca was filled with urates. No pharyngeal or esophageal lesions were observed.

Histopathological examination of the skin lesions revealed hyperplasia of the stratum spinosum of the epidermis, eosinophilic intracytoplasmic inclusion bodies in the hyperplastic cells and parakeratosis. Areas of necroses and bacterial infiltration were present in the hyperplastic epithelium of the left foot.

Virus particles were observed in the negatively stained preparation, although they were not plentiful. The virions were oval, had an outer coat of filaments that criss-crossed the surface and measured $265 \pm 19 \times 353 \pm 10 \mathrm{~nm}$ at their widest parts.

\section{Transmission Sfudies}

Lesions did not develop on the feet of the two great horned owls, but small (approximately $5 \mathrm{~mm}$ diameter), firm nodules with ulcerated surfaces were seen at 46 days at the sites of inoculation in the two red-tailed hawks. The birds were not observed between the 39th and 46th days post-inoculation, but lesions had not been observed on the 39th day. The nodules increased slightly in size over the next 3 days, and an excision biopsy was performed on one hawk on the 49th day post-inoculation. The nodule on the other bird remained approximately the same size for another 14 to 21 days, but the surface appeared more cornified and less ulcerated. This lesion then regressed and was no longer visible

- Fisher Scientific, Don Mills, Ontario. 


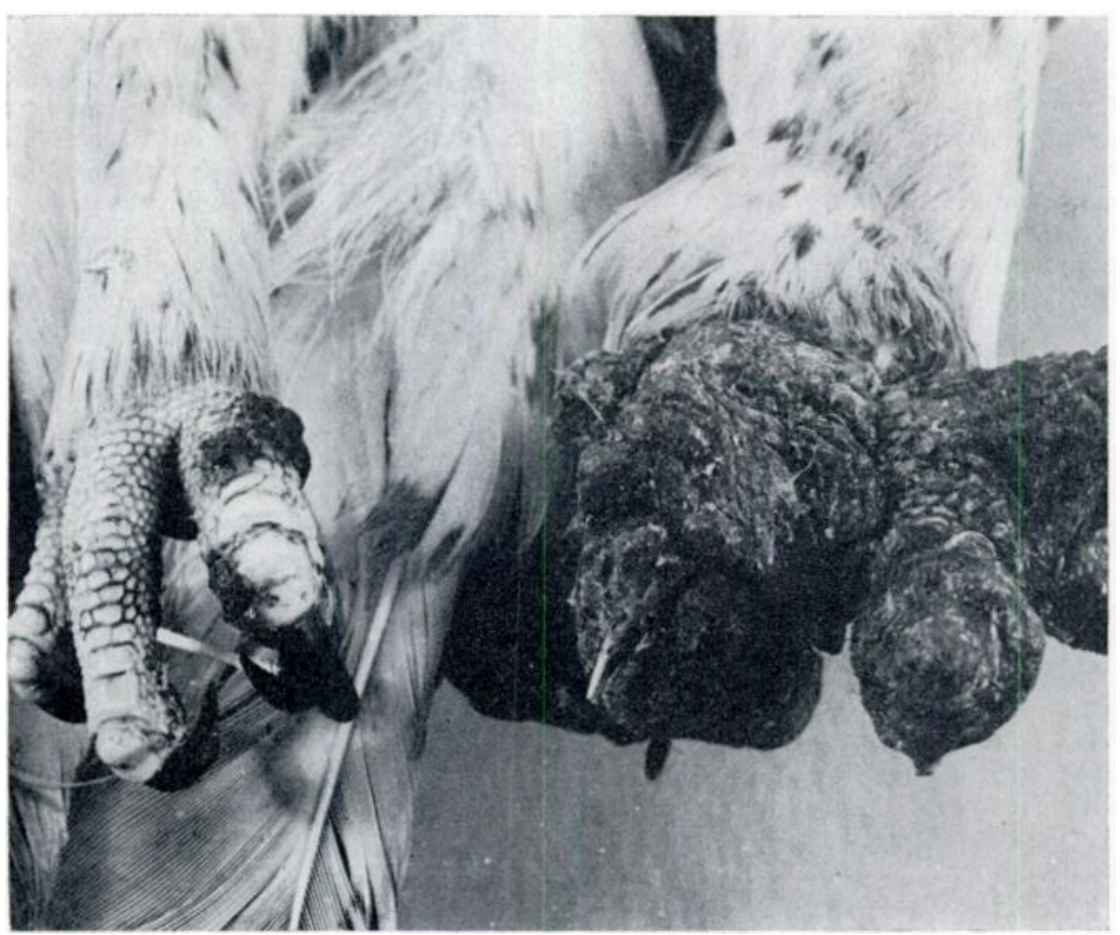

FIGURE 1. Feet of rough-legged hawk with pox infection.

by the 98 th day post-inoculation. Histologically, the skin lesion on the first redtailed hawk was similar to the smaller lesions in the rough-legged hawk.

Sections of the stratum spinosum only were examined with the electron microscope. In the cytoplasm of the epithelial cells of the stratum spinosum, oval accumulations of virus particles were seen (Figure 2). These were considered to be inclusion bodies. The virus particles had an outer envelope and an oval or dumbbel-shaped internal core, and measured $203 \pm 10 \times 396 \pm 19 \mathrm{~nm}$. Electrondense granular material was present in the matrix of the inclusion bodies.

\section{DISCUSSION}

The gross, histopathologic and electron microscopic finding in the rough-legged hawk, and in the red-tailed hawks inocu- lated with lesion material from the rough-legged hawk, were typical of avian pox." Transmission of the infection between the two Butco species (i.e.. roughlegged hawk and red-tailed hawk) indicates that the virus is not a monospecific strain, but failure to infect the great horned owls suggests that there may be some generic specificity. Transmission studies utilizing other species are needed to verify this.

The fact that, following capture, the rough-legged hawk was observed to feed on muskrat carcasses, even though it was too weak to fly, indicates its emaciated condition was not the result of inability to locate or ingest food. However, the extensive left foot lesion was observed to inhibit walking and undoubtedly interfered with the capture of prey. In fact, 


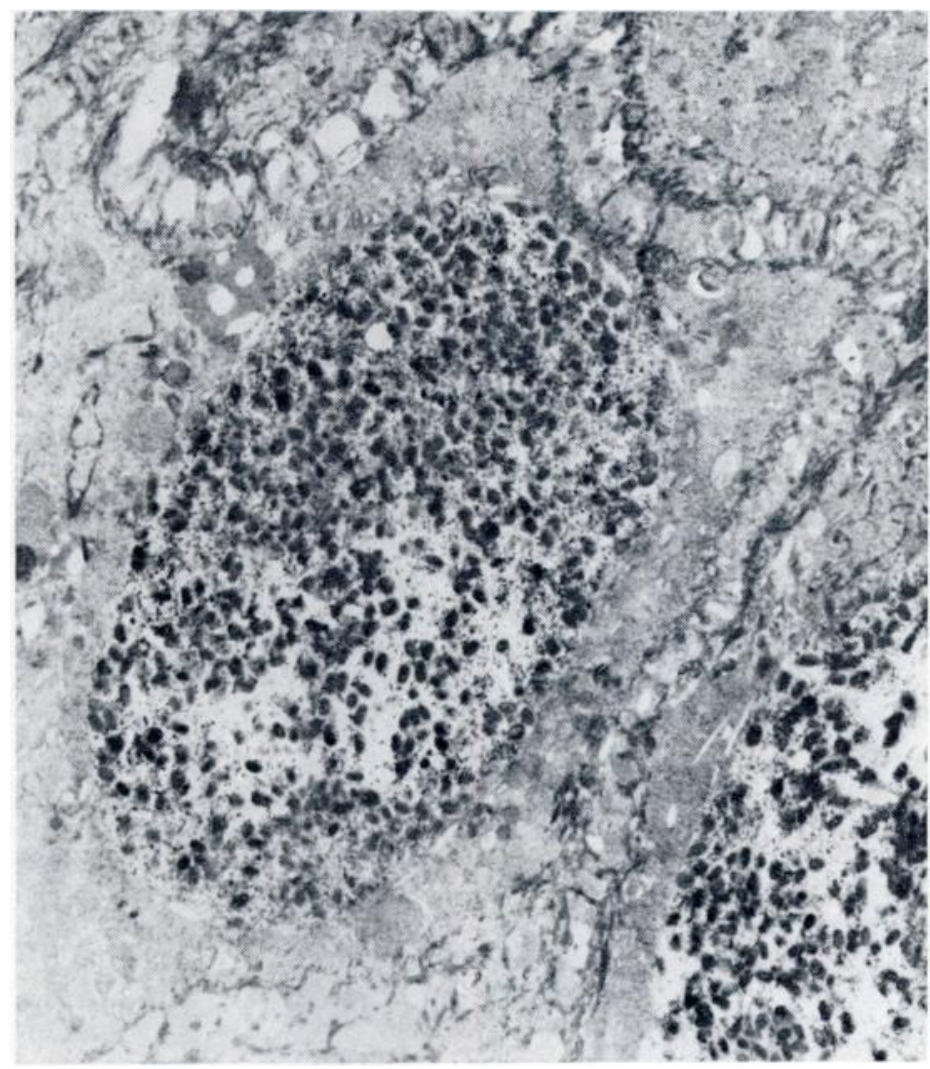

FIGURE 2. Electron micrograph of cytoplasmic inclusion in epithelial cell of stratum spinosum of red-tailed hawk artificially infected with pox virus from rough-legged hawk. X5720

the hawk may have stayed in the vicinity of the farmstead in an attempt to utilize a more abundant supply of small rodents. Inability to capture prey efficiently because of extensive foot lesions, es- pecially when coupled with chronic blood loss from lesions and high energy demands of cold weather, apparently can contribute to the mortality from pox infections in birds of prey.

\section{Acknowledgements}

The authors extend their appreciation to Mr. and Mrs. Louis Bryl of Webster, North Dakota, for their concern in capturing and seeking aid for the rough-legged hawk and to $\mathrm{Mr}$. David Goeke, Manager of Sullys Hill National Game Preserve, for submitting the bird for postmortem examination and providing the history of the case. 


\section{REFERENCES}

1. BURNETT, E. L. 1943. Fowl pox. pp. 481-492 in Diseases of Poultry. Edited by H. E. Biester and L. Devries. The Iowa State College Press, Ames, Iowa.

2. CHEVILLE, N. F. 1966. The cytopathology of swine pox in the skin of swine. Am. J. Path. 49: 339-352.

3. COOPER, J. E. 1969. Two cases of pox in recently imported peregrine falcons (Falco peregrinus). Vet. Rec. 85: 683-684.

4. GREENWOOD, A. G. and W. F. BLAKEMORE. 1973. Pox infection in falcons. Vet. Rec. 93: 468-470.

5. HALliWELL, W. H. 1972. Avian pox in an immature red-tailed hawk. J. Wildl. Dis. 8: 104-105.

6. KARSTAD, L. 1971. Pox. pp. $34-41$ in Infectious and Parasitic Diseases of Wild Birds. Edited by J. W. Davis et al. The Iowa State University Press, Ames, Iowa.

7. KIRMSE, P. 1967. Pox in wild birds: An annotated bibliography. Wildl. Dis. 49.

8. MOFFATT, R. E. 1972. Natural pox infection in a golden eagle. J. Wildl. Dis. 8: $161-162$.

9. VENABLE, J. H. and R. COGGESHALL. 1965. A simplified lead citrate stain for use in electron microscopy. J. Cell. Biol. 25: 407-408. 